\title{
Affordable Housing Policy in China: New Developments and New Challenges
}

\author{
Wei Shi ${ }^{1}$, Jie Chen ${ }^{2}$, Hongwei Wang ${ }^{3}$
}

\begin{abstract}
This paper shows that the balance of several overriding policy objectives has determined the direction of the affordablehousing policy in urbanChina. The priorities of the Chinese affordablehousing policy agenda include promoting economic growth and urbanization through the efficient allocation of housing-related resources and ensuring political consolidation and social stability by maintaining housing affordability for mainstream society. The achievements and problems of affordable housing programs in post-reform China are introduced. We also discuss what lessons we can draw from the Chinese affordable housing policy developments.
\end{abstract}

Keywords: Housing policy, housing affordability, China, urbanization

\footnotetext{
${ }^{1}$ A/Professor, Shanghai Finance University. Shanghai China Email: sw_rosestone@126.com

2 Professor, Shanghai University of Finance and Economics, Shanghai, China; Email: chen.jie@mail.shufe.edu.cn

3 President and Professor, Shanghai Finance University. Shanghai, China Email: wang3050@sina.com
} 


\section{Affordable Housing Policy in China: New Developments and New Challenges}

\section{Introduction}

Since the market-oriented reform of its welfare housing system in 1998, China has made impressive progress in improving the housing conditions for hundreds of millions of urban residents within a short period of time(Man 2011). However, the affordability of housing still poses one of biggest challenge in urban China(Yang \& Chen 2014).

The existing research has shown that a shift in the provisional responsibility of urban housing from work units to the market was a precondition of the market-oriented reforms of state-owned enterprises in the early 1980s (Wu 1996; Shaw 1997; Wang et al. 2005), which made the revitalization of the Chinese urban economy possible. Nonetheless, the Chinese post-reform urban housing system has put too much priority on economic functions of housing investment, while largely overlooking the housing needs of low-income households (Chen et al. 2010). In recent years nearly all major Chinese cities has experienced rocketing growth of housing price: the national-level mean housing price soared from to 1,854 RMBper sqm in 1998 to 5,932 RMB per sqm in 2014 (NBSC 2015). The mounting housing affordability crisis in urban areas has become an acute social issue and even pose threats to political stability (Chen, Yang, et al. 2014). As described in a recent speech delivered by the Chinese President Jinping Xi, affordable housing policy has been attached with political significances such as the inevitable requirement to promote social justice and ensure the public sharing the achievements of reform and development'(Xi 2013).

The discussion of the Chinese housing policy is often located in the literature of the East Asia model of housing regimes. It is widely hold that national housing systems in East Asiashare an important common to use housing development as a means to drive urban development and economic growth(Doling \& Ronald 2014). Particularly, the research has elaborated the rationales of why the provision of owner-occupied housing is a pillar of welfare under productivist welfare regimes in East Asia. Through promoting asset-based welfare among homeowners, East Asian governments expect the family asset can functions as social security and the building up of "asset-based security" can preserve self-sufficiency and reduce the citizens' demand to develop onerous and costly welfare states (Groves et al. 2007; Ronald 2007; Doling \& Ronald 2010; Ronald \& Doling 2012).

In Esping-Andersen (1990), the Polanyi's concept of'de-commodification' plays a central role in defining both what constitutes social rights and what is welfare state: the former are viewed in terms of 'the degree to which they permit people to make their living standards independent of pure market forces', while the latter is hold 'when a service is rendered as a matter of right, and when a person can maintain a livelihood without 
reliance on the market'(Doling \& Ronald, 2014, pp.22). Under the influence of Esping-Andersen (1990), housing has been often treated in western countries as part of the package of social rights with appropriate degrees of de-commodification. In contrast, in the 1990s and early 2000s, housing provision in East Asia was typically featured with deep commodification and intensified marketization. Even public housing in the region is typically delivered by the states as commodified asset goods so that it can "help to resist potential de-commodification that would threaten to extend the autonomy of workers and a sense of social rights to public goods" (Doling \& Ronald, 2014, pp.18).

However, the complete state withdraw from housing provision in East Asia has triggered persistent housing market turbulence, economic volatility, social fragmentations and wealth polarization (Ronald \& Chiu 2010). Accompanied by the increasing demand for social rights and democracy, the rapid ageing of the population, falling fertility and the erosion of the traditional family model, the East Asian housing model is under rapid reshaping(Doling \& Ronald 2014). This is same in China.

Against these backgrounds, this paper focuses on investigatingwhy the Chinese government recently adopted a radical shift of post-reform housing policy and launched a massive construction plan of 36 million units of public housing between 2011 and 2015 . This paper notes that the latest developments in the Chinese housing system should be closely connected to the adoption of the "harmonious society" development ideology of 2006 as well as the new urbanization strategy formallylaunched in 2013, which is essentially a reorientation of the development strategy of theChinese economy(World Bank and DRC 2013). In its focus, the recent public housing program serves as a propelling engine to promote accommodating millions of low-income migrants in cities permanently under the new urbanization strategy. Interestingly, the literature suggests that housing practices in China at the moment are actually not very different from those in western countries if we take the stage of development of urbanization in China into consideration(Chen, Stephens, et al. 2014). In many western countries, public housing was developed at a similar stage of rapid industrialization to accommodate industrial workers (Malpass \& Murie 1999; Chen, Stephens, et al. 2014).From this perspective, one may conclude that governments across the world are adopting "similar strategies" to address similar housing issues when facing the pressures of rapid urbanization (Chen, Stephens, et al. 2014). However, the Chinese experience of achieving a balance between economic prosperity and housing affordability during the rapid urbanization process is still unique and thus may carry wide policy implications.

\section{The backgrounds of the Chinese post-reform housing system}

Since 1998, the housing provision system in urban China has evolved gradually with economic development and the urbanization process.The shift in the provision responsibility of urban housing from work units to the market has made rural-to-urban migration and labor mobility much easier than before. However, the housing market 
boom has also been accompanied by a rapid increase in house prices, making home purchase increasingly unaffordable for low- and middle-income households and, in particular, for young workers and migrants (Chen et al. 2010; Yang \& Shen 2008). The housing market is thus polarizing property wealth between different tenures and different socioeconomic and demographic cohorts (Logan et al. 2010; Man 2011). Meanwhile, the lack of affordable housing provision has produced severe obstacles for the sustainability of urbanization in China. The Chinese central government has over time reached a consensus that the imbalance between the housing sector and socioeconomic development can be largely attributed to the insufficiency and inefficiency of the state provision of housing (Qi 2009; MOHURD 2011; Li 2011).

\section{Housing stock}

An overwhelming majority of the public housing stock was quickly privatized within a few years after 1998. It is estimated that the size of the privatized public urban housing stock at the end of the 20th century was 2.5 million sq. m (roughly 70 percent of total public housing stock) and associated with an implicit market value of approximately RMB 2.5 trillion, or approximately 32 percent of China's GDP in 1998 (Adams 2009). Privatization has helped raise home ownership levels among the permanent urban population to approximately 90 percent (cf. Table 1). It is estimated that 40 percent of (permanent) urban residents live in privatized housing. Enjoying a form of 'state legacy welfare', they are protected from the rising costs of housing in the market sector (Chen et al. 2010).

Table 1. Tenure Distribution of Housing in Urban China, 2011

\begin{tabular}{|r|l|r|}
\hline Tenure type & Description & $\begin{array}{l}\text { Share } \\
(\%)\end{array}$ \\
\hline Owner-occupied & & 89.3 \\
\hline $\begin{array}{r}\text { Owned Private } \\
\text { housing }\end{array}$ & $\begin{array}{l}\text { Self-built after 1949 or old private housing } \\
\text { built before 1949 }\end{array}$ & 11.2 \\
\hline $\begin{array}{r}\text { Owned Market } \\
\text { housing }\end{array}$ & $\begin{array}{l}\text { Bought through the market and built by } \\
\text { developers }\end{array}$ & 40.0 \\
\hline $\begin{array}{r}\text { Privatized Public } \\
\text { housing }\end{array}$ & $\begin{array}{l}\text { Bought during the 1980-2000 housing } \\
\text { reforms }\end{array}$ & $\begin{array}{l}\text { Including both private and public rental } \\
\text { housing }\end{array}$ \\
\hline \begin{tabular}{l} 
Rental lease \\
\hline
\end{tabular}
\end{tabular}

Source:NBSC (2011).

In tandem with the massive construction boom since the 1998 reforms, the improvement in housing conditions in urban Chinais substantial. According to the sixth national census (2010) (NBSC 2012), the total construction space of the occupied housing stock in urban China doubled from 10.3 billion sq. $\mathrm{m}$ in 2000 to 20.3 billion sq. $\mathrm{m}$ in 2010 , and the 
average housing space per person in urban China resulted in a 35.6 percent growth over the same period (22.36 sq. m vs. 30.33 sq. m).

However, the improvement in housing conditions in urban China is substantially uneven across regions. The housing conditions are generally quite good in the developed eastern region, but much poorer in the underdeveloped western area(cf. Figure 1). Further, there are vast variations in housing conditions across cities with different sizes. Generally speaking, the prevalence of housing overcrowding is still high in large cities where the migrant population grows fast, for instance, Shanghai and Beijing.

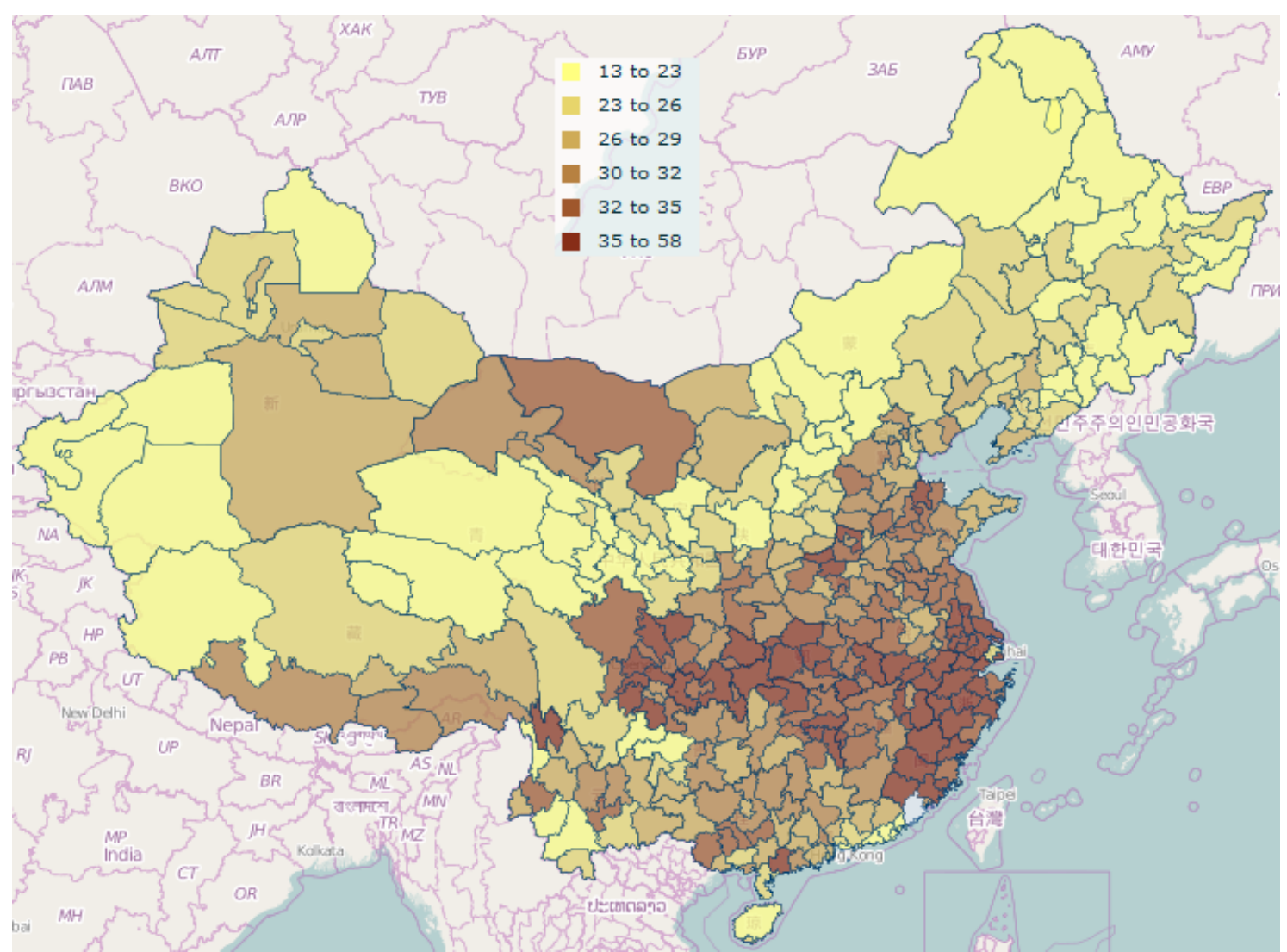

Figure 1: Housing space per person at the prefectural-city level in China (2010) (sq. m).

\section{Housing provision system}

The market-oriented housing reform in 1998 aimed to shift the provision role of the state to the market. Nevertheless, the state did not plan to withdraw completely from the housing provision.A two-tier public housing system consisting of Cheap Rental Housing (CRH) and Economic Comfortable Housing (ECH) was introduced in 1998. The CRH program is targeted a accommodating lowest-income households with nominal rent rate, playing a residual role as in U.S. and other western countries (Chen, Yang, et al. 2014). The ECH program is expected to promote homeownership within low-to-medium income households who could not afford buying home at market price. 
While the policies and mandates are set by the central government, the responsibility of producing and distributing ECH is placed on the shoulders of local governments. However, local governments usually appropriate state-owned land to real estate developers at zero or very low price and then direct them to take responsibility of the finance and construction of ECH. The profit for real estate developers are capped around $3 \%$, so as to keep the price of ECH at a level that affordable for most low-income households. To get ECH, individuals need to apply to local housing authority and pass the qualification check that including local residence permit (hukou), asset, income and living space requirement.

ECH was officially designed as the predominant form of post-reform housing provision in the milestone document of 1998 housing reform (SC[1998]No.23). However, with the pressure of boosting GDP growth through a real estate boom (Rosen \& Ross 2000), the importance of public housing rapidly waned after 1998. In 2003, the State Council formally gave up the idea of $\mathrm{ECH}$ as the main form of post-reform housing (SC[2003]No.18). The role of public housing in the housing provision has droppedheavily since then (cf. Figure 2).

In recent years, there are several new forms of public housing in urban China. The SOH(shared ownership housing), which has been launched since 2010 in Shanghai, resembles very much ECH(economic comfortable housing). However, $\mathrm{SOH}$ clearly requires that about half of the capital gain when selling the housing should be returned to the government while ECH does not explicitly have such regulation. The PRH (public rental housing) is the only type of public housing that accessible to migrants (residents without local hukou) and its rent is generally only slightly lower than the market rate. Around 2008, the PRH emerged in some southern cities as a learning from the Public Housing in Hong Kong. In 2010, the PRH was promoted bythe Ministry of Housing and Urban-Rural Development (MOHURD) as a favored national mode of public housing (MOHURD[2010]No.87). Since 2014, the CRH has been merged with PRH where CRH is treated as a special segment of PRH (MOHURD[2013]No.178). 


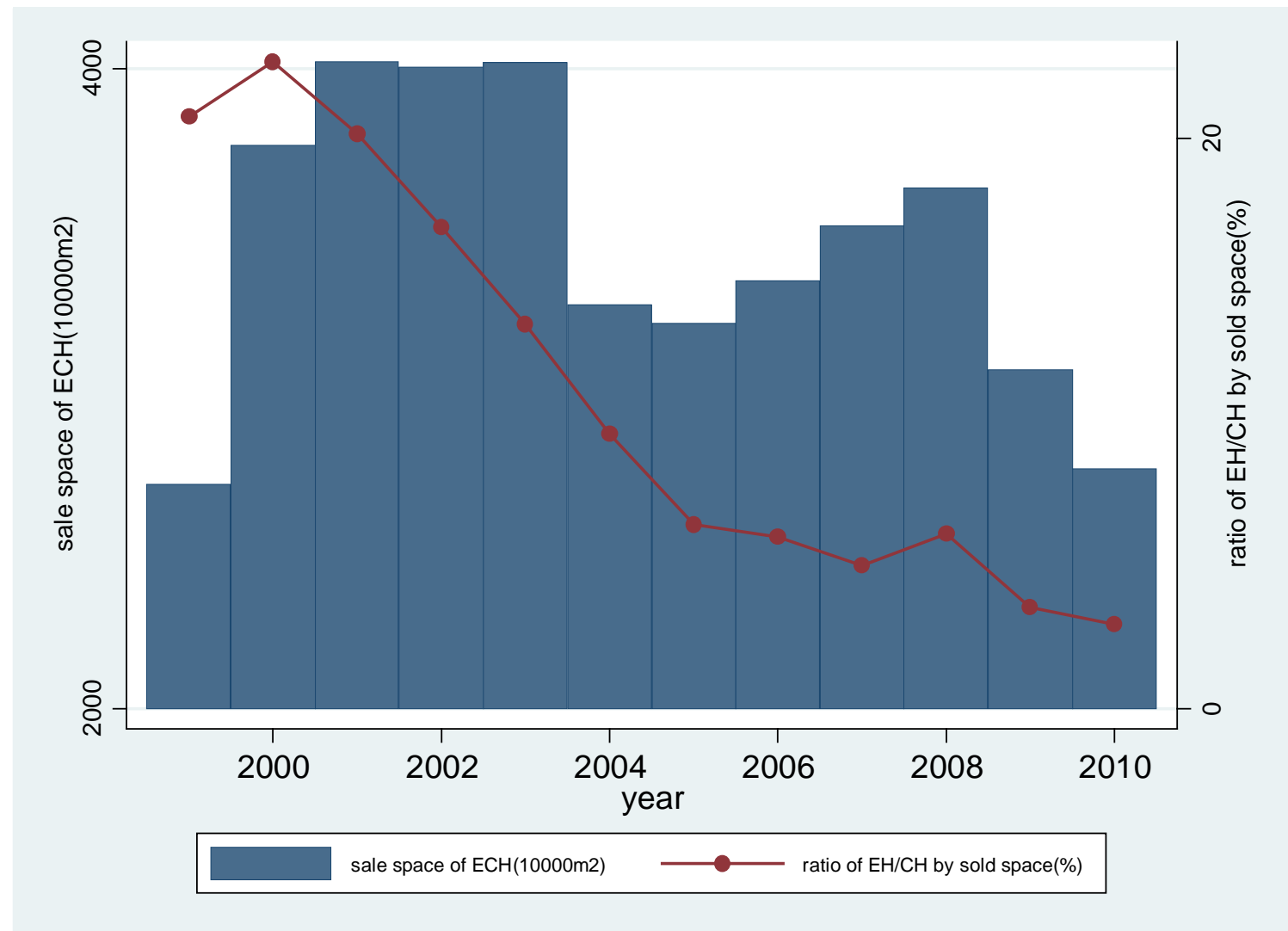

Figure 2: The supply of ECH and its share in total housing in urban China (1998-2010)

\section{Housing market development and growing affordability pressures}

Since 1999, the housing prices in urban China have maintained a strong upward trend, with the exception of a slight downward price adjustment in 2008 due to the shock of the global financial crisis. Clearly, rapid urbanization is one of the fundamental driving forces behind the recent developments in the urban housing market in China(World Bank and DRC, 2013).At the national level, the mean housing price in 2014 was approximately 3.15 times that in 1999 and 1.6 times that in 2008. In large cities such as Beijing and Shanghai, housing prices have risen much higher than the national average. A persistent increase in housing prices, particularly in China's major cities after 2008 (cf. Figure 3), affects both the sustainability of the property market and social stability (Yang \& Chen 2014).

Nonetheless, Chinese households' incomes also grow substantially since the 1998 housing reform. At national level, it appears that the housing affordability index has not worsen much since 1999 (cf. Figure 4), and recent research confirms this point (Chen et al. 2010). However, households' purchasing power varies significantly across regions, and widening differences in regional housing market have created a volatile context for local housing affordability (cf. Figure4). 
Table 2: Types of Public Housing in Post-reform Urban China

\begin{tabular}{|c|c|c|c|}
\hline Type & & Date & Description \\
\hline Old Public Housing & & between 1949 and 1998 & built by the state \\
\hline Privatized & & & privatized at discount rate \\
\hline Non-privatized & & & under control of local housing authorities \\
\hline New Public Housing & & after 1998 & built or subsidized by the state \\
\hline & Target group & Eligibility requirement & \\
\hline \multicolumn{4}{|l|}{ For sale } \\
\hline $\begin{array}{r}\text { Capped-Price Housing } \\
(\mathrm{CPH})\end{array}$ & $\begin{array}{r}\text { low-to-middle-income } \\
\text { and middle-income } \\
\text { households }\end{array}$ & $\begin{array}{r}\text { local residence permit (Hukou), } \\
\text { income threshold, } \\
\text { without owned-home }\end{array}$ & $\begin{array}{r}\text { The price is usually capped at around } 70 \% \text { of } \\
\text { market level and the buyers generally need to } \\
\text { hold it at a minimum of } 5 \text { years. }\end{array}$ \\
\hline $\begin{array}{r}\text { Shared ownership } \\
\text { housing }(\mathrm{SOH})\end{array}$ & $\begin{array}{r}\text { Middle-income } \\
\text { households }\end{array}$ & $\begin{array}{r}\text { local residence permit }(\text { Hukou), } \\
\text { income threshold, } \\
\text { without owned-home }\end{array}$ & \\
\hline \multicolumn{4}{|l|}{ For renting } \\
\hline $\begin{array}{r}\text { Cheap Rental } \\
\text { Housing }(\mathrm{CRH})\end{array}$ & $\begin{array}{l}\text { lowest-income } \\
\text { "house-poor" households }\end{array}$ & $\begin{array}{r}\text { residence permit (Hukou), } \\
\text { income and asset threshold, } \\
\text { living space threshold }\end{array}$ & \\
\hline $\begin{array}{r}\text { Public Rental } \\
\text { Housing (PRH) }\end{array}$ & all households & $\begin{array}{r}\text { no local residence requirement } \\
\text { no income or space threshold }\end{array}$ & \\
\hline
\end{tabular}

Source: Author's own summary based on various official documents. 


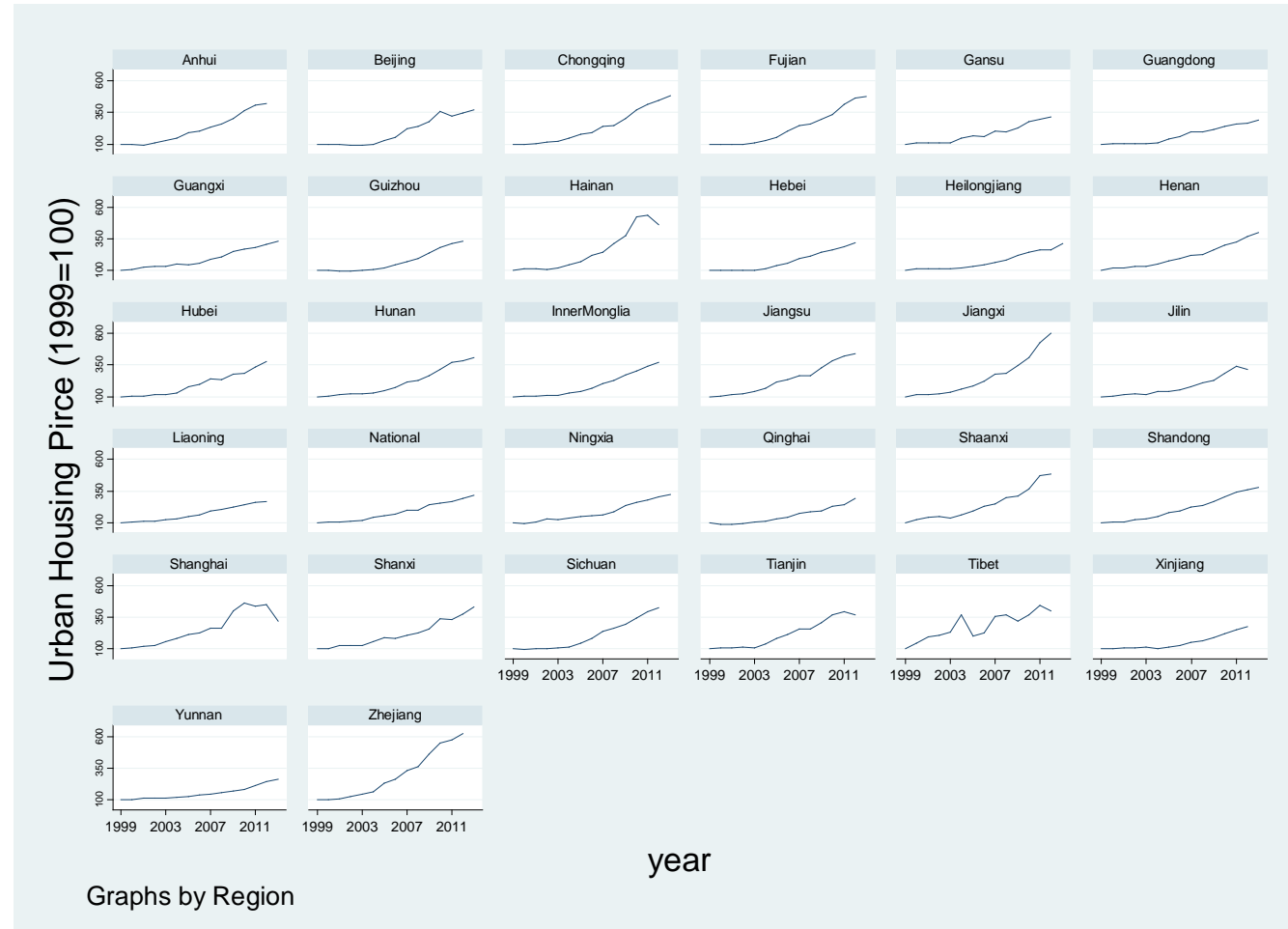

Figure 3: The national and provincial trend of urban housing price in China (1999-2013) Source: National Bureau of Statistics of China.

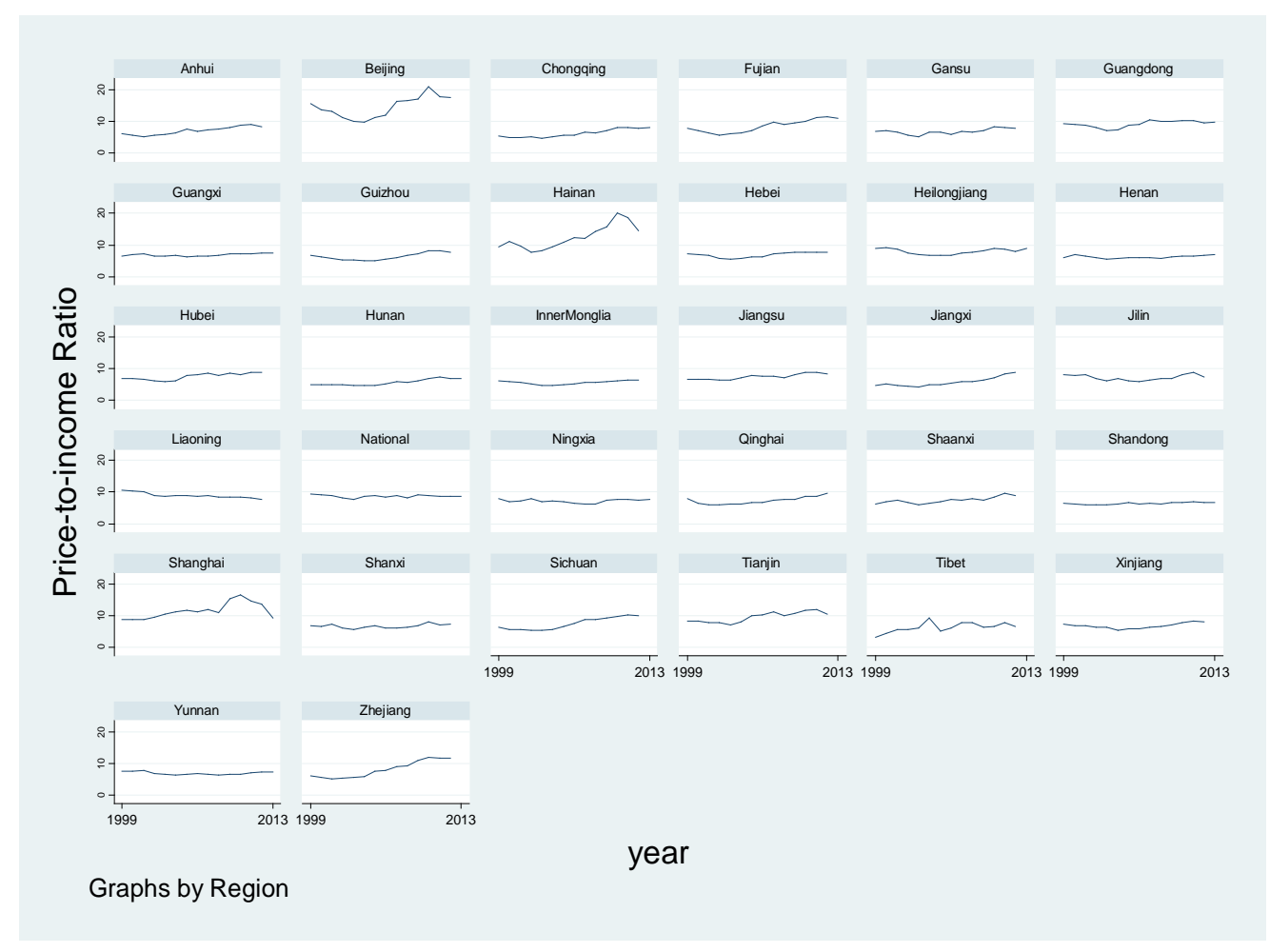

Figure 4: The national and provincial trend of price-to-income ratio (PIR) in China Source: National Bureau of Statistics of China.

Note: PIR= mean price of a 90-sqm housing divided by mean household income. 


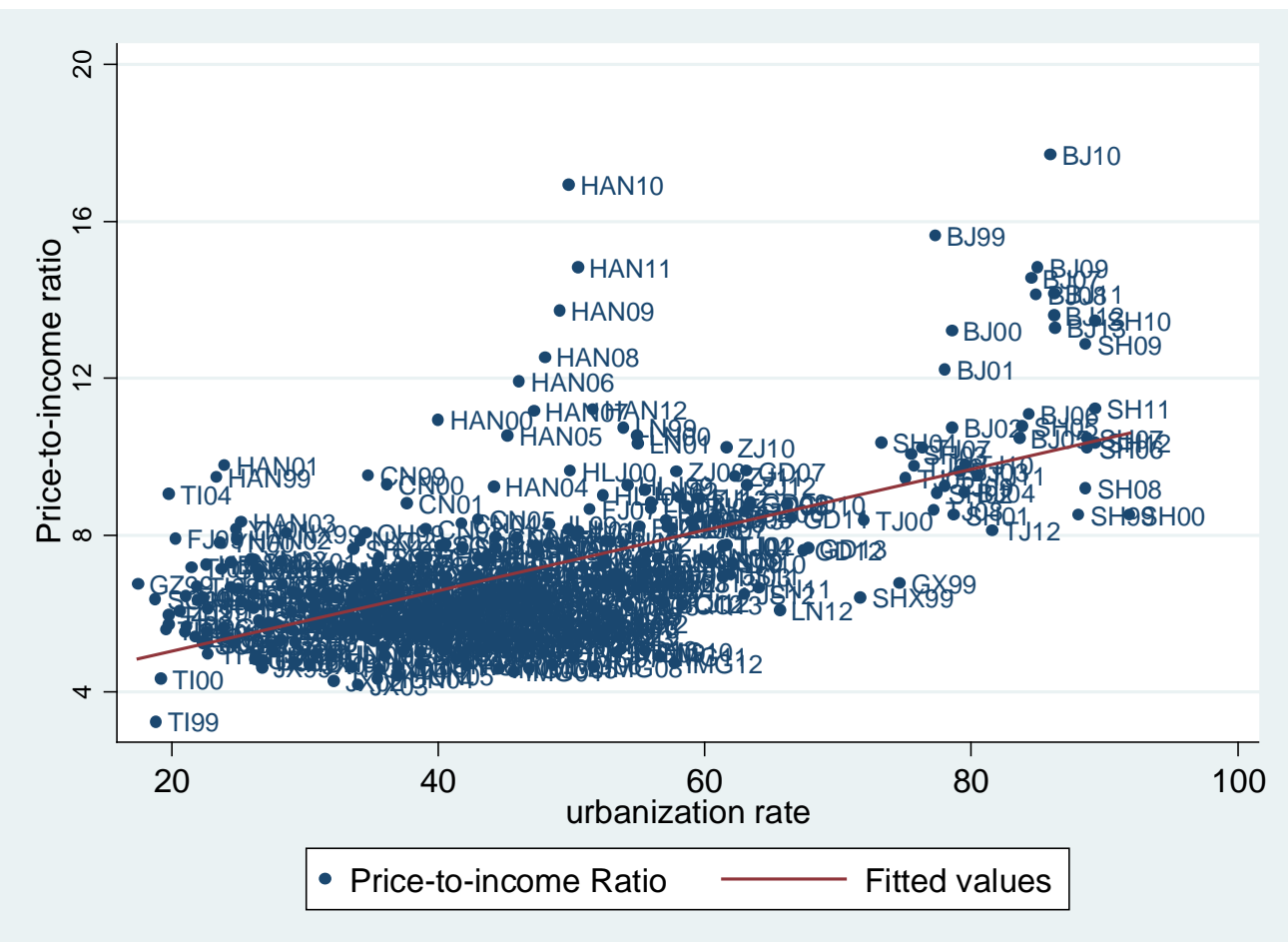

Figure 5: Housing affordability and urbanization in China (province-year observations Source: based on the data from the National Bureau of Statistics China

Examining the regional variations in the price to income ratio (PIR), we find it is highly positively correlated with the urbanization rate (cf. Figure 5), which suggests that regions experiencing faster urbanization are more likely subject to housing affordability pressures and thus need more flexible modifications in local housing systems. A recent study also shows that migration has significantly contributed to the upsurge of housing prices in Chinese cities since 2000(Lu et al. 2014).

\section{Housing market development as a constraint to urbanization}

While the marketization of housing provision has greatly helped facilitate rural-to-urban migration and also created millions of job opportunities for migrants, the upsurge in housing prices also make decent housing accommodation increasingly unaffordable for migrants (Chen et al. 2010; Yang \& Shen 2008). Over time, the lack of affordable housing provision has posed severe challenges for the sustainability of urbanization in China. Despite rapid urbanization, migration in China is still subject to many institutional restraints. The hukou system, the urban registration system that was introduced in 1958 (although it had precedents), has been promulgated as an official tool to control the free movement of people between urban and rural areas (Chan \& Buckingham 2008). Administration regulations issued in 1982 known as "custody and repatriation" (C\&R) authorized the police to detain migrants if they did not have a local residence permit (hukou) or temporary living permit in the city and repatriatethese "illegal migrants"to the settlements where their permanent hukous were issued (Chan \& Buckingham 2008). Although the C\&R law was formally abolished in 2003, the hukou system remains in force today and continues to constrain population mobility. Under the hukou system, 
migrants are largely excluded from the welfare package reserved for local residents, including unemployment insurance, health care, pension, housing benefits and even their children's right to enter local schools (PFPC 2012).

The hukou system has been constantly noted as a major constraint in the housing consumption of migrants(Wu 2004; Sato 2006). At the national level, an official survey indicates that the homeownership ratio among migrants was around just 10 percent in 2010 (PFPC 2012), which is in sharp contrast with the figure of 89 percent among permanent urban residents (NBSC 2011). The exclusion of migrants from the local housing welfare system further exacerbates migrants' difficulties in the Chinese urban housing market (Sato 2006).

\section{Affordable housing developmentin post-reform China}

A clear shift in political priorities occurred in 2006 when President Hu Jintao's doctrine of the 'harmonious society' was adopted by the ruling Communist Party(World Bank and DRC 2013). Initially, housing did not feature significantly in the doctrine of 'harmonious society' in urban areas. However, a rapid upsurge in housing prices in most major Chinese cities since 2003has made housing affordability issues become one of China's top social concerns (Chen et al. 2010).

In 2008, a program of 7.5 million units of public housingwas formed as part of China's stimulation package in response to the Global Financial Crisis (Chen, Yang, et al. 2014). At that time, this was widely thought to have been a temporary intervention in much the same manner as the intervention in response to the Asian Financial Crisis a decade earlier. However, in 2009, the target was doubled and in 2011, a huge 36 million units public housing program was later announced for the plan period 2011-15. With this, the proportion of the country's formal housing stock through public provision would almost double from 11 percent to 20 percent by the end of 2015 (MOHURD 2011). The Chinese public housing program includes a mix of 'products' for different segments of the market (cf. Figure 6). Approximately 60 percent of public housing provisions are forms of subsidized ownership and 40 percent are for rent (cf. Table 3). 


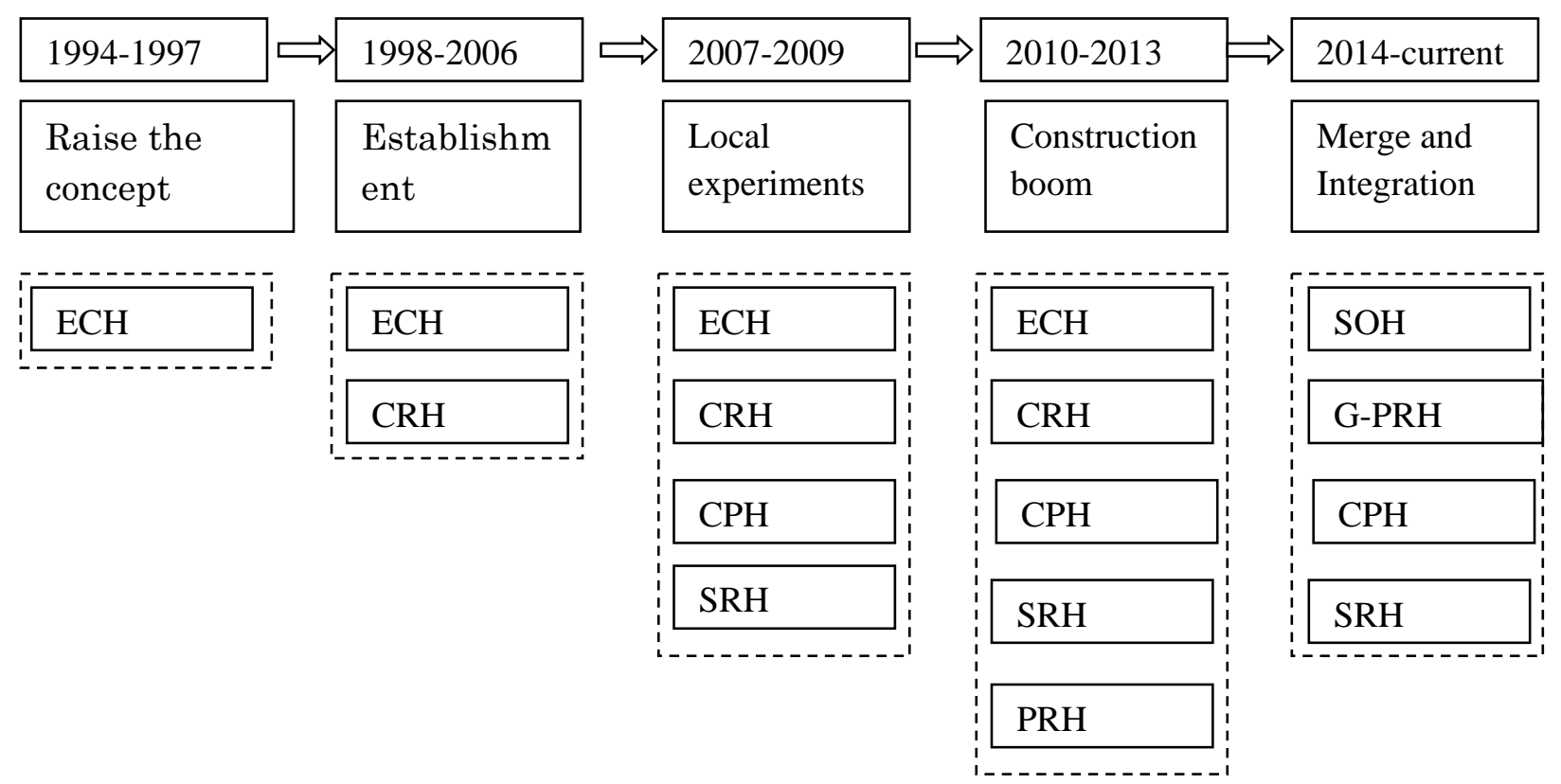

Figure 6: The development of affordable housing programs in urban China

Source: authors' summary based on public information

Note 1: The definition of each type of housing should refer to Table 2.

Note 2: The SRH(shanty renovation housing) has existed in China for decades but only since 2007 they are accounted as a type of affordable housing program.

Note 3: Since 2014, CRH was merged in PRH as a special segment of PRH.

Table 3.The supply of public housing in urban China (2010-2014)(unit: 10000 units)

\begin{tabular}{|c|c|c|c|c|c|c|c|c|}
\hline \multirow{2}{*}{ Year } & \multicolumn{6}{|c|}{ Construction Plan } & \multirow{2}{*}{$\begin{array}{c}\text { Newly } \\
\text { Started }\end{array}$} \\
\cline { 2 - 9 } & SRH & PRH & CRH & CPH & ECH & Total & Growth & \\
\hline 2010 & 280 & 0 & 180 & 0 & 120 & 580 & $49.9 \%$ & 590 \\
\hline 2011 & 400 & 220 & 160 & 200 & 1000 & $72.4 \%$ & 1043 \\
\hline 2012 & & & & 700 & $-30 \%$ & 781 \\
\hline 2013 & & 700 & 630 & $-10 \%$ & 666 \\
\hline 2014 & 470 & 630 & 700 & $11.1 \%$ & 720 \\
\hline
\end{tabular}

Source: report from China index academy and MOHURD website.

The rationale of the new public housing program

Official statistics suggest that China is currently experiencing the largest scale of urbanization ever known in human history: the urbanization ratio in China will reach 69 percent in 2030, and the urban population will increase by more than 300 million over the period of 2011-2030(United Nations 2012), which implies that there will be a strong and sustained momentum for the expansion of housing demand in urban China in the 
next few decades. However, the land available for urban residential use in China is small compared to its fast-growing urban population. Moreover, to ensure its own food security, China has a strict quota on agricultural land development(Ding \& Lichtenberg 2011). Thus, there is a decreasing supply of suitable sites for residential development.The expansion of low-cost public housing programs,however, is expected to increase the supply of affordable housing to meet the accommodation needs of a growing number of new entrants who have little hope of purchasing homes at market prices.

"The recent emphasis on public housing for the poor is a good example of how government resources can be used to address a pressing social need" (World Bank and DRC 2013).Nevertheless, there continues to exist a wide suspicion that in China, state housing provision is just an important economic driver rather than socially necessary (Wang \& Murie 2011).The new public housing programwas oncemore commonlyconsidered a regulation tool to control spiralinghousing prices after several rounds of regulations failed to cool down the overheating residential property marketsas well as an economic vehicle to counteract the shocks of the global economic downturn. It appears that the Chinese central government juggles the provision of low-income housing towards conflicting economic and socio-political goals and, therefore, creates constant changes in low-income housing policy(Huang 2012).

I.

II.

\section{Urban development concerns}

For local governments, the major interest in supplying public housing is driven by the urgent need to smooth relocation costs, which have soared due to the rapid increase in market housing prices. The emphasis on shanty-town resettlement is thus a striking feature of the Chinese public housing program. There are reasons to believe that the dominance of Shantytown Renovation Housing (SRH) in recent public housing developmentis directly tied to the local governments' goal to promote urban redevelopment by providing low-cost housing to relocated residents.

This finding, however, should not be surprising because the state provision of resettlement housing has been a critical factor underlying the so-called property-led massive urban redevelopment in China ever since the mid-1990s (He \& Wu 2005; Shin 2009). Assistance for shanty-town dwellers is linked to resettlement, which can take the form of low-cost home ownership, low-cost rental housing, or cash compensation(Chang $\&$ Chen 2013). The local governments simply cannot afford for compensation to grow at the same rates as the soaring prices of market housing. Thus, the main function of SRH is to re-house expropriated urban and rural households at low costs and thus help to facilitate "growth-promoting" urban regeneration. 


\section{Urbanization concerns}

It should be noted that the primary objective of the Chinese 36-million public housing programis toensure the success of the new urbanization strategy (MOHURD 2011; Li 2011).The shift in housing policy after 2007 recognized the importance of cheap rental housing for the segment of the migrant population that cannot afford to purchase subsided-ownership housing, which is reflected in the relatively high priority attached to it within the program(Chen, Yang, et al. 2014). In the ECH scheme, the main qualifications for eligibility include residence status (hukou), household income, the number of people, average living area per capita and the total value of assets of a family(Yang \& Chen 2014).For PRH, however, the general rule regarding qualification is not very clearly defined by the central government, which leaves local governments with substantial freedom to make their own allocation policies.

The eligibility conditions are much broader and vary substantially from city to city. In Beijing, Guangzhou and Shenzhen, income per capita, total assets and current living floor space are assessed. In Beijing, applicants who are qualified for the CHP, ECH and $\mathrm{CPH}$ can apply for PRH. However, in Shanghai and Chongqing, the current living area is the only eligibility condition for PRH. In addition, urban migrant workers without local hukou,but with a stable job and income sources are allowed to apply for PRH in Beijing, Shanghai, Chongqing, and Chengdu, but not in Guangzhou, Shenzhen or Hangzhou(Chen, Yang, et al. 2014). The variations in allocation criteria for PRH reflect different local political preferences.

For many cities, $\mathrm{PRH}$ is regarded not simply as a residual safety net for low-income households, but more as a tool to support local economic development(Chen 2014). According to guidelines on accelerating the development of PHR released by MOHURD and six other departments in July 2010 (MOHURD[2010]No.87), PRH was introduced with the main purpose of solving the temporary and interim accommodation needs of migrants, new workers and house-poor households ( $\mathrm{Li}$ 2011). However, local governments are more likely allocate public housing as subsidized benefits to specific target groups that they prefer, such local civil servants, highly educated people and skilled labor that they want to attract and retain (Wang and Murie 2011). The provision of public rental housing is thus an effective selective tool used by policymakers to retain skilled or semi-skilled workers in large cities. For example, a recent study shows that the recent development of $\mathrm{PRH}$ projects in Shanghai is mainly the result of a deliberate urban development policy in line with other strategies such as city marketing and gentrification (Chen 2014). Because there is a very limited security of tenure in the private rental housing market in China(Man 2011), PRH in the form of "gated communities" is very attractive for the middle class (Wu 2005), who highly value residential stability. In this respect, $\mathrm{PRH}$ provides an alternative to homeownership with an affordable and guaranteed leasing contract, offering decent housing to the newly emerged middle class. 
It is worth noting that the current housing provision system in China is actually not very different from those in western countries if one considers the stage of development of the country (Chen, Yang, et al. 2014). China is at a stage of rapid industrialization and urbanization. The social composition of the urban population not only includes the emerging middle class but also a re-emerging and ever-expanding working class (which differs from the socialist workers of the pre-reforms period). Though commercial housing targeting the new middle class in cities flourishedduring the first decade of the 21st century, the working class housing problem was not properly addressed. The poor quality private rental housing offered by the urban villages provided a temporary solution in the past, but has resulted in great social costs over time. For example, many urban villages are unregulated and have become havens for illegal activities and even crimes. Typically few public amenities are available in urban villages, and the community environment is particularly hazardous for tenants' children (Zheng et al. 2009; PFPC 2012). The alliance of local landless farmers, rural-to-urban migrants, and young educated professionals now represents a large proportion of the expanding urban population (PFPC 2012). The new public housing program is aimed at this group of people (MOHURD 2011; Li 2011).

\section{Lessons from the Chinese affordable housing policy}

After almost one decade after the mass privatization of urban welfare housing stock in 1998, the Chinese government has again pledged huge investment on social housing in recent years. The 36-million social housing program is underpinned by the basic housing right (decent housing for all) policy launched since 2007, which marks a watershed in the Chinese housing regime and signals the resurgence of direct state intervention in housing provision(Wang \& Shao 2014). However, the new public housing program has a clear policy target to offset the slowdown of external demand by stimulating domestic demand. It also explicitly aims to smooth the fluctuation of real estate market. Thus, housing policy in China is still an extension of economic policy. The Chinese experience regarding the interaction between the housing system and urbanization is highly unique, but it clearly indicates that an effective housing system that can responsively provide sufficient affordable housing is an essential component to the success of inclusive and equitable urbanization. Below we offer some policy recommendations for establishing an affordable housing system that is more supportive to urbanization.

\section{Achieving a balance between different policy priorities in the housing policy design}

The priority of Chinese urban housing policy in the first decade of 2000 was exclusively to develop for-profit property development that could help generate enormous taxes and increase land revenue. The housing affordability issue of low-income disadvantaged groups, particularly rural-to-urban migrants, has been largely neglected in the Chinese urban housing policy so far. This mode of housing regime is clearly unsustainable because it has produced too many social conflicts and even threats to political stability (Chen, Yang, et al. 2014). Heavy reliance on the real estate sector also makes the 
Chinese urban economy too susceptible to the risks of property cycles. In addition, the Chinese banking system has accumulated undue risks from investing too much credit in mortgages and other forms of real estate loans (People's Bank of China 2014). This model also hinders urbanization in China by not only making the costs of decent accommodation increasingly unaffordable for migrants but also pushing up local wages, deterring labor mobility, hampering large cities from achieving the full potential of the agglomeration effect and reducing the competiveness of these cities. For example, a recent study notes that the severe constraint of land supply in the east is a key reason housing prices, and consequently wages, have increased in these cities, which has damaged the competitiveness of the Chinese urban economy (Lu et al. 2014).

So far urbanization in China features a clear "dual-track" pattern, in the sense that migrants do not have access to urban welfare in the same manner as the permanent residents of the cities (Shen 2006). With the slogan of "human being-oriented urbanization", the new urbanization strategy appears to represent a 'critical juncture' in Chinese public policy.The primary objective of this strategy is to promote inclusive urban growth so that an increasing number of migrants can finally settle in the cities (Koen et al. 2013; OECD 2014). The strategy eventually aims to re-orientate the economy away from being based on exporting goods cheaply to the rest of the world to greater orientation towards boosting domestic consumption(Li 2012; World Bank and DRC 2013). It is expected that domestic consumption will be raised through the development of more public services, the lack of which are perceived as a major cause of China's very high savings rate (i.e., people save for old age, medical care and children's education)(OECD 2014). There is also ample evidence that the hukou system severely constrains and depresses migrants' consumption propensity. Allowing migrants to settle in the cities and increasing their demand for public services is a key to the success of the national economic rebalance.

From these perspectives, the Chinese housing policy is no longer subordinated to economic policy, but is rather an integrated part of economic policy. Nonetheless, the Chinese housing system is still undergoing drastic transformations, and it is obviously too early to draw any definite conclusion. Further research is needed to identify whether and how the Chinese housing system has shifted from "productivism" to "developmentalism". However, because the switch in the housing regime is already an important part of this macro political and economic transition, the recent transformations ofthe Chinese urban housing system must be understood within the overall transformation of China's development ideology from "productivism welfare" to "developmental welfare" (Chen, Yang, et al. 2014).

\section{Put housing affordability as the primary priority of the housing policy}

It is true that the housing policy may need to meet several policy objectives, but ensuring affordability should always be the primary priority. The massive public housing program 
is designed to help balance economic growth and provide stability in light of the increasingly short supply of low-cost housing, high levels of inflation and a growing wealth gap. Fortunately, the new urbanization strategy has openly put accommodating low-income migrants in the cities as a central target, and various solutions, including developing massive-scale public housing, have been attempted. The current national prioritization of public housing in China signals a sharp change in the housing policy of previous decades, addressing negative externalities and inefficiencies in China's short-lived post-housing reforms period. To make the affordable housing movement sustainable, there is a need to promote the UN-honored concept of "housing rights", where adequate housing is considered a basic human right and is be protected not only by governmental measures but also laws (UN-HCHR 2009). However, housing sector complexities can never be totally coordinated by a central authority, and a legal system that ensures the delivery of sufficient affordable housing should be established.

\section{Reduce the local state's fiscal dependence on land revenue}

The conflict between affordability concerns and the objective of economic growth within the Chinese housing system is largely due to the local state's heavy reliance on land-based urban financing, which is contingent on housing market booms. Land and housing policiesare among the Chinese government's most important tools for fine-tuning the economy. A housing policy that addresses the needs of the majority is critical for any government during the transition. Today the government is looking at a long-term land allocation plan oriented toward economic restructuring as a tool to control economic cycles. Nonetheless, to promote human-based urbanization rather than "land urbanization", the state needs to restructure the central-local fiscal relationship, reform the tax system of local states and encourage experimental innovations in urban infrastructure financing, i.e., new forms of PPP (public-private partnership). For example, several hybrid arrangements of PPP between local governments and private investors have emerged in the last decade (ADB 2008). However, an enabling setting of the regulatory and policy arrangements is a precondition to the success of any type of PPP project. Meanwhile, there is a need for concerted attempts to develop the Chinese municipal bond market.

\section{Establishing an effective and efficient housing finance system}

The current plan to rapidly increase investment and construction in public housing may result in an increased supply of affordable housing for needy families. However, we believe that the establishment of a finance system for such affordable housing is at least equally important. The Chinese government should promote the use of a variety of financing tools and instruments to attract social capital to publichousing investment and lower the cost of borrowing for low- and middle-income families. A well-functioning housing finance system will contribute to the expansion of home ownership, the development of housing markets and employment, economic growth and wealth accumulation, and social and political stability. Several options are worthy of the 
Chinese government's consideration and experimentation. For example, based on the experience of public housing management in Hong Kong, China, the Chinese local governments may try financing public rental housing projects from the private capital market, i.e., through some form of REITs (Real Estate Investment Trusts). Another possibility is to restructure HPF (housing provident fund-the worker's compulsory saving scheme) so that it can work as a long-term stable and cheap funding pool for financing public housing development and operation (Chen \& Deng 2014), similar to the integrated CPF (Central Provident Fund), the public housing model in Singapore.

Acknowledgment: The research is supported by the funding from National Science Foundation of China [71173045; 71573766], Key Social-Science Research Project of the Ministry of Education of China (13JZD009) and the "Shu Guang" project (13SG35) from Shanghai Education Development Foundation.

\section{References}

Adams, B., 2009. Macroeconomic Implications of China Urban Housing Privatization, 1998-1999. Journal of Contemporary China, 18(62), pp.881-888.

ADB, 2008. Public-Private Partnership (PPP) Handbook, Manila: Asian Development Bank.

Chan, K.W. \& Buckingham, W., 2008. Is China Abolishing the Hukou System? The China Quarterly, 195(6), pp.582-606.

Chang, Y. \& Chen, J., 2013. Public housing in Shanghai: a tool with multiple purposes. Housing Finance International, 27(Winter), pp.68-85.

Chen, J., 2014. The Development of New Public Rental Housing in Shanghai. Critical Housing Analysis, 1(1), pp.26-34.

Chen, J. \& Deng, L., 2014. Financing Affordable Housing through Compulsory Saving: the Two-decade Experience of Housing Provident Fund in China. Housing Studies, 29(7), pp.937-958.

Chen, J., Hao, Q. \& Stephens, M., 2010. Assessing Housing Affordability in Post-reform China: A Case Study of Shanghai. Housing Studies, 25(6), pp.877-901.

Chen, J., Stephens, M. \& Man, J.Y., 2014. The Future of Public Housing: Ongoing Trends in the East and the West J. Chen, M. Stephens, \& J. Y. Man, eds., Berlin: Springer Berlin Heidelberg. 
Chen, J., Yang, Z. \& Wang, Y.P., 2014. The New Chinese Model of Public Housing: a step forward or backward? Housing Studies, 29(4), pp.534-550.

Ding, C. \& Lichtenberg, E., 2011. Land and Urban Economic Growth in China. Journal of Regional Science, 51(2), pp.299-317.

Doling, J. \& Ronald, R., 2010. Home ownership and asset-based welfare. Journal of Housing and the Built Environment, 25(2), pp.165-173.

Doling, J. \& Ronald, R., 2014. Housing East Asia: Socioeconomic and Demographic Challenges J. Doling \& R. Ronald, eds., Hampshire: Palgrave Macmillan.

Esping-Andersen, G., 1990. The Three Worlds of Welfare Capitalism, Princeton: Princeton University Press.

Groves, R., Murie, A. \& Watson, C.J., 2007. Housing and the New welfare State: perspectives from East Asia and Europe, Ashgate Publishing Limited.

He, S. \& Wu, F., 2005. Property-led Redevelopment in Post Reform China: A Case Study of Xintiandi Redevelopment Project In Shanghai. Journal of Urban Affairs, 27(1), pp.1-23.

Huang, Y., 2012. Low-income Housing in Chinese Cities: Policies and Practices. China Quarterly, 212(4), pp.941-964.

Koen, V. et al., 2013. Policies for Inclusive Urbanisation in China, Paris.

Li, K., 2012. Deepening the strategy of expanding domestic consumption through furthering the reform and openness. Qiu Shi(in Chinese).

Li, K., 2011. Implementing the massive-scale public housing program and improving housing policy and housing provision system step-by-step. Qiu Shi(in Chinese), 53(8), pp.3-8.

Logan, J.R., Fang, Y. \& Zhang, Z., 2010. The Winners in China's Urban Housing Reform. Housing Studies, 25(1), pp.101-117.

Lu, M., Chen, B. \& Ou, H., 2014. Rationality or Bubble? An Empirical Study on Urbanization, Migration and Housing Price. World Economy(in Chinese), 36(1).

Malpass, P. \& Murie, A., 1999. Housing Policy and Practice 5th ed., Hampshire: Palgrave Macmillan.

Man, J.Y., 2011. China's Housing Reform and Outcomes J. Y. Man, ed., Cambridge, MA: Lincoln Institute of Land Policy.

MOHURD, 2011. The Minster of MOHURD's report of latest progress of public housing program on the meeting of the 11th NPC (National People's Congress) Standing Committee held in October 27, 2011. Sina. Available at: http://finance.sina.com.cn/focus/rdxwbzf/index.shtml [Accessed November 28, 2011]. 
NBSC, 2011. Series reports on China's economic and social development achievements during the 11th five-year planning period (2006-2010): No.9. The Official Website of National Bureau of Statistics of China (NBSC). Available at:

http://www.stats.gov.cn/ztjc/ztfx/sywcj/201103/t20110307_71321.html [Accessed March 1, 2013].

NBSC, 2015. Statistical Communique of the People's Republic of China on the 2014 National Economic and Social Development. The Official Website of National Bureau of Statistics of China (NBSC). Available at: http://www.stats.gov.cn/tjsj/zxfb/201502/t20150226_685799.html [Accessed February 26, 2015].

NBSC, 2012. Tabulation on the 2010 People Census of the People's Republic of China. The Official Website of National Bureau of Statistics of China (NBSC). Available at: http://www.stats.gov.cn/tjsj/pcsj/rkpc/6rp/indexch.htm [Accessed March 1, 2013].

OECD, 2014. China: Structural reforms for inclusive growth, Paris.

People's Bank of China, 2014. The 2013 Report on the Use of Credit by Financial Agencies. Available at: http://www.pbc.gov.cn/publish/diaochatongjisi/3172/2014/2014012417130983382383 4/20140124171309833823834_.html [Accessed January 20, 2014].

PFPC, 2012. Report on China's Migrant Population Development 2012 National Population and Family Planning Commission of P.R. China (PFPC), ed., Beijing: China Population Press.

Qi, J., 2009. Housing Problems of Low-income Families in China. In The 22nd Session of the Governing Council of UNHabitat. Nairobi: The Governing Council of UNHabitat.

Ronald, R., 2007. Comparing Homeowner Societies: Can We Construct an East-West Model? Housing Studies, 22(4), pp.473-493.

Ronald, R. \& Chiu, R.L.H., 2010. Changing Housing Policy Landscapes in Asia Pacific. International Journal of Housing Policy, 10(3), pp.223-231.

Ronald, R. \& Doling, J., 2012. Testing home ownership as the cornerstone of welfare: Lessons from East Asia for the West. Housing Studies, 27(7), pp.940-961.

Rosen, K.T. \& Ross, M.C., 2000. Increasing Home Ownership in Urban China: Notes on the Problem of Affordability. Housing Studies, 15(1), pp.77-88.

Sato, H., 2006. Housing inequality and housing poverty in urban China in the late 1990s. China Economic Review, 17(1), pp.37-50.

Shaw, V.N., 1997. Urban housing reform in China. Habitat International, 21(2), pp.199212.

Shen, J., 2006. Understanding Dual-Track Urbanisation in Post-Reform China: Conceptual Framework and Empirical Analysis. Population, Space and Place, 12(5), pp.497-516. 
Shin, H.B., 2009. Residential Redevelopment and the Entrepreneurial Local State: The Implications of Beijing's Shifting Emphasis on Urban Redevelopment Policies. Urban Studies, 46(13), pp.2815-2839.

UN-HCHR, 2009. The Right to Adequate Housing, Geneva: the Office of the United Nations High Commissioner for Human Rights, United Nations Office at Geneva.

United Nations, 2012. World Urbanization Prospects: The 2011 Revision, New York.

Wang, Y.P. \& Murie, A., 2011. The New Affordable and Social Housing Provision System in China: Implications for Comparative Housing Studies. International Journal of Housing Policy, 11(3), pp.237-254.

Wang, Y.P. \& Shao, L., 2014. Urban Housing Policy Changes and Challenges in China. In J. Doling \& R. Ronald, eds. Housing East Asia: Socioeconomic and Demographic Challenges. Hampshire: Palgrave Macmillan.

Wang, Y.P., Wang, Y. \& Bramley, G., 2005. Chinese housing reform in state-owned enterprises and its impacts on different social groups. Urban Studies, 42(10), pp.1859-1878.

World Bank and DRC, 2013. China 2030: Building a Modern, Harmonious, and Creative High-Income Society, Washington, D.C.: The World Bank.

Wu, F., 1996. Changes in the structure of public housing provision in urban China. Urban Studies, 33(9), pp.1601-1627.

Wu, F., 2005. Rediscovering the "Gate" Under Market Transition: From Work-unit Compounds to Commodity Housing Enclaves. Housing Studies, 20(2), pp.235-254.

Wu, W., 2004. Sources of migrant housing disadvantage in urban China. Environment and Planning $A$, 36(7), pp.1285-1304.

$\mathrm{Xi}$, J., 2013. Speech at the collective learning meetings of CCP politburo regarding housing issues. Xinhua News.

Yang, Z. \& Chen, J., 2014. Housing Affordability and Housing Policy in Urban China, Berlin and New York: Springer.

Yang, Z. \& Shen, Y., 2008. The affordability of owner occupied housing in Beijing. Journal of Housing and the Built Environment, 23(4), pp.317-335.

Zheng, S. et al., 2009. Urban Villages in China: A 2008 Survey of Migrant Settlements in Beijing. Eurasian Geography and Economics, 50(4), pp.425-446. 